\title{
Die etiek van sending as anti-Kyriargale bemagtiging en liefdesdiens: ' $n$ Fokus op 1 Tessalonisense en mag of bemagtiging
}

\author{
Author: \\ Jacobus Kok ${ }^{1}$ \\ Affiliation: \\ ${ }^{1}$ Department of New \\ Testament, University of \\ Pretoria, South Africa \\ Correspondence to: \\ Kobus Kok \\ Email: \\ kobus.kok@up.ac.za \\ Postal address: \\ University of Pretoria, \\ Lynwood Avenue, Pretoria \\ 0002, South Africa \\ Dates: \\ Received: 01 Sept. 2011 \\ Accepted: 05 Feb. 2012 \\ Published: 23 Apr. 2012 \\ How to cite this article: \\ Kok, J., 2012, 'Die etiek van \\ sending as anti-Kyriargale \\ bemagtiging en liefdesdiens: \\ ' $n$ Fokus op 1 Tessalonisense \\ en mag of bemagtiging', \\ HTS Teologiese Studies/ \\ Theological Studies 68(1), \\ \#Art. 1170, 11 pages. http:// \\ dx.doi.org/10.4102/hts. \\ v68i1.1170
}

C 2012. The Authors. Licensee: AOSIS OpenJournals. This work is licensed under the Creative Commons Attribution License.
The Christian concept 'mission' is experienced by some as a negative term in the postmodern age of relativism and sensitivity with regard to the perspective and the rights of others. In this article it is postulated that the term 'mission' is only negative when mission is understood as an aggressive propagandistic persuasion of others from a position of power (moral high ground). This definition however, is a result of a male-dominated, Kyriarchal (male dominated) perspective, and by implication is ethnocentric and reductionistic in nature. Feminist and postcolonial perspectives open the way for an alternative definition of 'mission', which can open up fresh perspectives about mission and ethics in the early Church and these could be considered and in turn could have far-reaching implications for the manner in which the Christian mission is understood in a post-modern context. In this article it is investigated in which way the early Christian ethics of mission created the space within which traditional imperial dominance, gender, race and ethnicity was transformed with an alternative symbolic universe resulting from a reconceptualisation of power or empowerment and loving service from a Christological perspective.

\section{Inleiding}

Die Christelike begrip 'sending' word deur sommiges as 'n negatiewe term beleef in 'n postmoderne tyd van relativisme en 'n sensitiwiteit vir die perspektief en regte van die ander. Myns insiens word die begrip sending net negatief verstaan as sending die aggressiewe propagandistiese oortuiging van iemand anders behels vanuit 'n posisie van mag (morele hoë grond). Hierdie definisie van sending is egter 'n resultaat van 'n manlike gedomineerde, Kyriargale ${ }^{1}$ (manlik gedomineerde) perspektief en is, met ander woorde etnosentries en reduksionisties van aard. Feministiese en postkoloniale perspektiewe open die weg vir 'n alternatiewe definisie van sending wat vars perspektiewe kan open waarbinne daar oor sending en etiek in die vroeë kerk nagedink kan word en verreikende implikasies kan inhou vir die wyse waarop daar oor sending gepraat word in 'n postmoderne tyd. Die tese wat ondersoek gaan word, is in watter mate die vroeë Christelike etiek van sending die ruimte geskep het waarbinne tradisionele imperiale dominasie, geslag, ras en etnisiteit uitgedaag was deur ' $n$ alternatiewe simboliese universum wat die resultaat was van 'n herkonseptualisering van mag en diens vanuit ' $n$ Christologiese perspektief. In die vroeë Christelike gemeenskappe het sosiale stratifikasie en binêre polarisasie plek gemaak vir intra- en ekstra-gemeenskaplike diens en wedersydse opbou wat gemotiveer was deur 'n missionêre metanarratief (vgl. 1 Tess 3:12; Gal 6:10). Laasgenoemde implisiete etiek het uiteindelik gelei tot die missionêre uitbreiding van die Christendom in die eerste drie eeue (vgl. Stark 1996).

\section{Die aard van mag}

Ek is dit eens met Van Henten, en dit is my veronderstelling, dat mag en geloofsbelange in een of ander vorm implisiet alomteenwoordig is in alle menslike aksie en interaksie. ${ }^{2}$ Mens kan selfs so ver as Van Henten gaan en argumenteer dat mag nie net ' $n$ inherente aspek van godsdiens is nie maar wesenlik tot die fenomeen godsdiens behoort ${ }^{3}$ (Van Henten 2012:8).

1.Vir die betekenis van die term 'Kyriargaal' kyk die bespreking hier onder.

2.Elke linguistiese interaksie dra die spore van die inherente sosiale struktuur wat dit besit en die sosiale struktuur wat dit wil vestig - wat nou saamhang met die implisiete simboliese magselemente wat teenwoordig is (Bourdieu 1991:2). Volgens Bourdieu gaan dit om die verwante vorms van mag en gesag wat basies implisiet is in alle vorme van kommunikasie situasies (Bourdieu 1991:8).

3.Indien laasgenoemde wel die geval is, sal mag as verskynsel ' $n$ belangrike onderwerp wees om te bestudeer teen die agtergrond van die eksponensiële groei van die Christendom in die post-apartheid en post-koloniale Afrikakontinent en ook in Asië. Volgens die jongste inligting en statistiek vind daar tans ' $n$ reusagtige swaartekrag-verskuiwing plaas in terme van die sentrum van die Christendom - weg van Europa en Noord Amerika in ' $n$ suidelike rigting: na Afrika. Daar kan dus gepostuleer word dat ' $n$ massiewe magsverskuiwing plaasvind, ' $n$ revolusie, wat dalk so groot kan wees as die oorgang van die Middeleeue na die moderne tyd, of dalk die Reformasie. Dit is presies hier waar die verband tussen die missionêre uitbreiding van die Christendom, die magselemente en die etiek konvergeer. Dit bring ons by die interessante vraag na wat ons kan leer uit die Bybelse tekste en die verband tussen die missionêre dimensie, mag en etiek. 
Ons spring weg met hierdie gedeelte van die artikel deur te besin oor kontemporêre magsteorieë en die implikasie daarvan vir die magsdiskoers in 1 Tessalonisense. Die veronderstelling is dat die magsdinamika in 1 Tessalonisense nie beperk is tot die gebruik van die terme wat eksplisiet

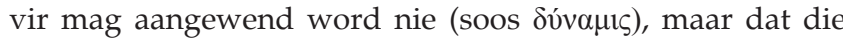
implisiete, denotatiewe, assosiatiewe en konnotatiewe betekenismoontlikhede verdiskonteer moet word (kyk Holmberg 1978). Die uitdaging lê dan juis daarin om die implisiete (vgl. Zimmermann 2009) magsdimensies te dekonstrueer teen die agtergrond van die moontlike sosiohistoriese konteks waarbinne die brief geskryf is.

Die Pauliniese magsdiskoers is nie eenvormig nie en die resultate waartoe die navorser kom is by implikasie ' $n$ resultaat van die perspektief waaruit daar na die saak gekyk word, synde of dit uit filosofiese, antropologiese, sosiologiese, polities of psigologiese hoeke bestudeer word. In hierdie artikel gaan ek aansluit by Ehrensperger (2007) wat onder meer vanuit ' $n$ filosofiese hoek die saak benader, maar dit ook duidelik maak dat die antieke konteks in ag geneem moet word en etnosentrisme en anakronisme in die proses vermy moet word.

Volgens kontemporêre magsteorieë is daar diverse vorme van mag. Alle vorme van mag is nie by implikasie negatief nie. In lyn met Wartenberg $(1990: 164,175)$ wys Ehrensperger (2007:28) op die feit dat mag inherent dinamies van aard is en dat die aard van magsrelasies voortdurend oor ' $n$ bepaalde tyd kan verander. ${ }^{4}$

Allen (1999:109) $)^{5}$ maak byvoorbeeld onderskeid tussen 'power-over' (domination), 'power-to' (empowerment) en 'power-with' (towards a shared goal [acting in concert]) (in Ehrensperger 2007:26, 30). Positiewe 'power-over' kan onder andere manifesteer in paternalistiese mag wat gemik is op die voordeel van die afhanklike persoon of agent (vgl. moeder-kind verhouding) en bevat ' $n$ transformatiewe dimensie, 'n bemagtigende dimensie (Ehrensperger 2007:26) wat uiteindelik kan kulmineer in 'n situasie waar die 'power over' nie langer benodig sou word nie (wanneer bemagtiging plaasvind). Hierdie vorm van mag word met ander woorde as suksesvol beskou in die geval waar dit 'renders itself obsolete' (Ehrensperger 2007:28). Die skadukant van hierdie vorm van mag is egter wanneer die ondergeskikte of afhanklike persoon in ' $n$ afhanklike posisie gehou word en die volle effek van die bemagtiging nie plaasvind nie (vgl. Speckmann 2009). ${ }^{6}$ Asimmetriese magsbeoefening hoef met ander woorde nie by implikasie dominerend te wees of negatief beskou te word nie (Ehrensperger 2007:31) (vgl. bv. 'n moeder 4.Die implikasie hiervan is dat die dinamika van mag in die Nuwe Testament sal
nie dieselfde wees in die verskillende korpusse van die Nuwe Testament en die
verskillende tye waaruit die Nuwe Testamentiese geskifte dateer nie (bv. die verskil
tussen Tessalonisense en die pastorale briewe as paulinise geskrifte nader aan die einde van die eerste eeu).

5.Kyk ook Allen (1999:97-118).

6.Speckmann (2009) is van mening dat Afrika in die greep van armoede vasgevang is en dat die internasionale finansiële hulp Afrika in 'n bedelaarsmentaliteit vasvang. In plaas daarvan dat Afrika bemagtig word, word Afrika in werklikheid eerder ontmagtig en afhanklik gehou. In sy boek gee hy ' $n$ Bybelse perspektief op eerder ontmagtig en afhanklik gehou. In sy boek gee hy ' $n$ Bybelse perspektief op
bemagtiging en argumenteer dat Jesus juis mense bemagtig het en hulle bevry het van magteloosheid en onderdrukking. en kind waar die asimmetriese verhouding bemagtigend meewerk). Binne die raamwerk van 'n verhouding waar bemagtiging plaasvind en asimmetriese mag positief inwerk, dien vertroue as ' $n$ kardinale waarde in die vorming van ' $n$ gesonde transformatiewe magsverhouding. Waar daar nie vertroue is nie en die afhanklike persoon geforseer word om teen haar wil op te tree, verander 'n potensieel bemagtigende verhouding in ' $\mathrm{n}$ dominerende verhouding (Ehrensperger 2007:29).

Die vraag wat ons dus na moet kyk indien ons 1 Tessalonisense bestudeer is watter implisiete kategorieë van mag of bemagtiging ter sprake is.

\section{Die magsdinamika in Paulus Anti-Kyriargale en anti-Imperiale magsuitsprake}

Die eerste eeuse mediterreense wêreld was gestruktureerd op 'n hiërargiese wyse en gekenmerk deur 'n patriargale sisteem wat deur mans gedomineer was. Dit was 'n wêreld waarin die keiser geheers het, 'n wêreld waarin 'the rule of emperor, lord, slave masters, husband, or the elite freeborn, propertied, educated gentleman dominated disenfranchised men and especially wo $/ \mathrm{man}^{\prime 7}$ (Nasrallah \& Schüssler Fiorenza 2009:9). Schüssler Fiorenza noem hierdie wêreld 'n wêreld van 'Kyriarchy' (saamgestel uit kurios [meester of Here] en archein [om te heers of domineer]) en wat geteoretiseer kan word as:

a compex pyramidal system of intersecting multiplicative social and religious structures or superordination and subordination, ruling and oppression. Kyriarchal relations of domination are built on elite male property rights as well as on the exploitation, dependency, inferiority, and obedience of wo/men who signify all those subordinated. (Nasrallah \& Schüssler Fiorenza 2009:9)

In die eerste eeu was die $K_{y}$ riargie ${ }^{8}$ die basis van die sosiokulturele, politieke en godsdienstige wêreld en was die sosiale en religieuse sisteme van die dag implisiet ingebed in die 'multiplicative intersectionality' van ras, geslag, etnisiteit en die mag van die Romeinse Ryk en die voortvloeiende stratifikasie, dominasie en diskriminasie wat uit hierdie sisteem voortgevloei het. Indien Kyriarchy as 'n analitiese heuristiese kategorie van ondersoek benut word, sal daar ondersoek ingestel kan word na die 'multiplicative interdependence of gender, race, class and imperial stratifications' wat in die antieke konteks en sy magsrelasies bestaan het, en die wyse waarop die Christelike identiteitsverstaan gevorm was rondom die kwessies van geslag, ras en etnisiteit en wat die impak was op die etiek en die sending in die vroeë kerk.

Die eerste-eeuse mediterreense wêreld was 'n dualistiese, gepolariseerde, kyriosentries gestratifiseerde wêreld wat grense getrek het tussen in-groep en uit-groep, beskermheer of kliënt (patron or clients), Grieke of Barbare, manlike of vroulik, slaaf of vry, beskaafd of onbeskaafd, ensovoorts (Nasrallah \& Schüssler Fiorenza 2009:11).

7.Schüssler Fiorenza gebruik die woord 'wo/man' om nie net te verwys na vrouens nie maar na enige persoon of groep wat deur ' $n$ Kyriargale sisteem gedomineer word.

8. Hierdie Afrikaanse neologisme 'Kyriargie' in Afrikaans is deur die outeur van hierdie artikel geskep na aanleiding van Schüssler Fiorenza (2009) se neologisme 'Kyriarchy'. 
Romeinse Kyriargale imperialisme was ook hiërargies gestruktureerd. Aan die toppunt van die Romeinse simboliese universum se piramiede het die keiser gestaan wat die pater patrum [vader van vaders] genoem was en selfs ook God van die gode en here van die here genoem was (Nasrallah \& Schüssler Fiorenza 2009:12).

Een van Paulus se eerste briewe was 1 Tessalonisense en is waarskynlik geskryf rondom die jaar 50 na Christus, tydens sy tweede missionêre reis in Agaie en Macedonië vanuit Korinte (Jewett 1986:53). ${ }^{9}$ In die Nuwe Testamentiese tye was Tessalonika die amptelike woning van die prokonsul van Macedonië. Volgens Jewett (1986:123) was die werklike mag in die hande van ongeveer vyf 'politarchs' gesetel wat primêr as agente van die Romeinse heerskappy gefunksioneer het. Volgens argeologiese ontdekkings het die stad haar sukses toegeskryf aan die voorsienigheid (benefaction) van Anthony en Octavius en het hulle ook ' $n$ tempel gebou ter ere van die keiser. Daar het ook 'n gevestigde priesterdom gefunksioneer wat gewy was aan die godin Roma en die keiser as god (en seun van god) (Jewett 1986:124).

In die tyd waarin 1 Tessalonisense geskryf is was die Romeinse imperiale heerskappy goed gevestig in die mediterreense wêreld (Ehrensperger 2007:9; vgl. ook Horsley 2004 en 1997). Onder die Romeinse imperiale ideologie van die dag moes alles beheer word. Alle aspekte van die lewe soos religie, ekonomie en politiek is beheer deur die Romeinse Ryk. In die magtige Romeinse Ryk het religie ' $n$ belangrike rol gespeel in Rome se magsgreep (Baltrusch 2002:48, 118). Daar het verskeie kultusse in die Ryk bestaan wat ' $n$ belangrike samebindende rol gespeel het om die verskillende provinsies binne die ryk te integreer ${ }^{10}$ (Ehrensperger 2007:9; Jewett 1986:126-127; Crossan \& Reed 2004:142). Religieuse toleransie het net gefunksioneer in so verre as wat dit nie die Romeinse imperiale ideologie en Rome se magsgreep bedreig het nie (Baltrusch 2002:118; Crossan \& Reed 2004:141-142). ${ }^{11}$ Volgens sommige geleerdes was die vroeë Christelike boodskap radikaal van aard en het dit juis die Romeinse imperiale ideologie implisiet uitgedaag.

Volgens Ehrensperger (2007:10) kon die openingswoorde

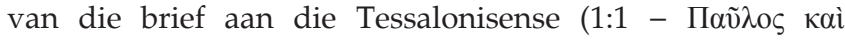

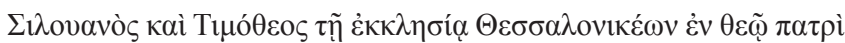

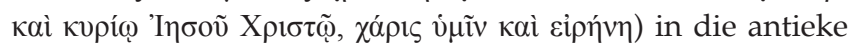
konteks deur sommige mense van die tyd beskou word as ' $n$

9. Kyk ook Van Aarde (2000:105-137) vir ' $n$ bespreking van 2 Tessalonisense waarin hy vanuit ' $n$ sosio-historiese hoek argumenteer dat laasgenoemde ' $n$ pseudografiese geskrif is wat in ' $n$ bepaalde sosio-historiese konteks verstaan moet word. Teenoor geskrif is wat in " $n$ bepaalde sosio-historiese konteks verstaan moet word. Teenoor die algemene opvatting in die verlede dat 2 Tessalonisense "n outentieke brief van Paulus was waarin Paulus die besorgdheid aangaande die uitgestelde eskatologiese verwagting van sy gemeente aanspreek, dat dit nie Paulus was wat die brief geskryf het nie en dat laasgenoemde nie die kwessie was wat die skrywer wou aanspreek nie.

10.Crossan en Reed (2004:160) stem saam: 'Imperial divinity was, quite simply, the ideology that held the Roman Empire together.

11.Vir eeue het die Jode se geloof in God en hulle verbondsverhouding met God (vgl. Gen 12) hulle identiteit en etos gevorm wat hulle dikwels in spanning gebring het met die Romeinse imperiale ideologie (vgl. Cicero, Pro Flacco 69) en tot wedersydse met die Romeinse imperiale ideologie (vgl. Cicero, Pro Flacco 69) en tot wedersyds spanning gelei het (Ehrensperger 2007:10) en ook ' $n$ implisiete magstryd behels het. Dit was dan presies op hierde punt waar die Christendom ' $n$ probleem geword het. Paulus se sendingopdrag was die boodskap van Jesus Christus die Seun van God, Koning en Here, verwagte Messias van die monoteistiese Joodse geloof wat gekruisig is deur die Romeinse Ryk. Die frustrasie wat die Roomse regering met die Jode gehad het, en dat daar geen god behalwe Jahweh is nie, het pas erger geword. deklarasie van oorlog ${ }^{12}$ - 'n ideologie wat direk in opposisie sou staan met die kyriosentriese magsaansprake van Rome. Deur Jesus Here en God te noem en 'n nabye verhouding tussen Jesus en God die Vader te skets, was 'n boodskap wat reg teen die imperiale ideologie ingedruis het.

Sommige geleerdes is van mening dat daar geen bewyse is dat die Christelike boodskap as anti-imperiale magsdiskoers verstaan kan word nie. ${ }^{13}$ Ek verskil egter hiervan deur te onderskei tussen anti-imperiale intensie en anti-imperiale konnotasie en die konsekwensies daarvan. Myns insiens kan daar by wyse van analogie aangetoon word dat die Christologiese en die Teologiese uitsprake van die vroeë Christelike gemeenskap anti-imperiale magsdiskoers konsekwensies kon inhou na aanleiding van die persepsie wat dit in die Romeinse Ryk kon geskep het, sonder om daarmee te sê dat die Christelike boodskap intensioneel antiimperialisties 'ontwerp' was. Die vraag is egter of ons hierdie anti-imperiale konnotasie en konsekwensie fenomeen kan koppel aan die vroeg-Christelike dokumente en spesifiek die Nuwe Testament, en by name Tessalonisense. Myns insiens word die assosiatiewe en konnotatiewe elemente van die anti-imperiale diskoers eksplisiet in die Nuwe Testament gevind met spesifieke verwysing na Paulus se optrede in Tessalonisense. Die outeur van Handelinge byvoorbeeld, met die gegewe dat Handelinge nie histories (contra Hengel 2003) die vita Pauli beskryf nie, toon minstens aan dat hierdie assosiatiewe verbande bestaan het in Handelinge 17:7 waar hy eksplisiet stel dat sommige vir Paulus aangekla het

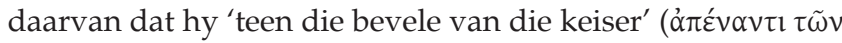

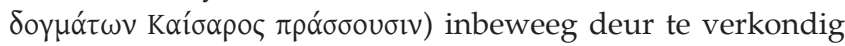
dat daar 'n ander koning is, naamlik Jesus.

Deur gelowiges kinders van hierdie God te noem, het by implikasie 'n bepaalde verhoudingsrealiteit uitgedruk, en was niks minder nie as ' $\mathrm{n}$ identiteitsmerker wat navolgers van Christus binne die dampkring van die alternatiewe gemeenskap geposisioneer het. In die openingswoorde van die brief wens Paulus die gemeente twee dinge toe,

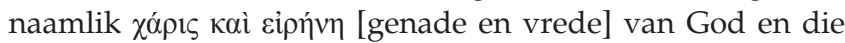
Here Jesus Christus. Die implikasie van hierdie seënwens is betekenisvol. Paulus impliseer dat God (en Jesus) die gelowiges se beskermheer (patron) is en dat God die gewer is van vrede, nie die keiser nie. ${ }^{14}$ Ehrensperger (2007) stel dit goed:

In the context of an empire which was organized as a strictly hierarchical, autocratic structure, a structure embodied by the absolute rules who claimed and was hailed to be 'the father of the fatherland', Savior, Peacemaker, etc., the mere claim to call no one 'father' except God, and to proclaim another Saviour or 12.Kyk Taubes (2004:16) in Ehrensperger (2007:10).

13. Hier verwys ek na die stimulerende gesprek rondom die kwessie waar dele van hierdie artikel aangebied was by ' $\mathrm{n}$ magskongres in Stellenbosch in 2011. Sommige van die kollegas het daarop gewys dat geleerdes versigtig moet wees om die Christelike boodskap as anti-imperiale diskoers te lees en dat daar nie tekstuele bewyse is dat die Christelike boodskap so verstaan was nie. Hierdie opmerkings het die ruimt die Christelike boodskap so verstaan was nie. Hierdie opmerkings het die ruimte geskep waarbinne ek hierdie vraag kon ondersoek. Hiermee dus erkenning aan prof. Pieter De Villiers wat die eerste vraag rondom hierdie kwessie
in die kongres geopper het.

14.Kyk Crossan en Reed (2004:166) vir argeologiese ontdekkings van ' $n$ altaar van Praeneste waarin daar eksplisiete verwysing bestaan na die pax ('peace') and securitas ('security') van Augustus. 
a peace other than the peace and justice of Rome was an act of resistance to the dominant and dominating imperial order. ${ }^{15}$ (pp. 10-11)

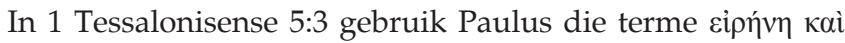
$\alpha \sigma \varphi \alpha ́ \lambda \varepsilon 1 \alpha$ [vrede en sekuriteit] op 'n negatiewe wyse, om diegene te beskryf wat met die wederkoms van Christus onverhoeds aan die slaap gevang sal word. ${ }^{16}$ Hierdie twee terme was bekende terme in die betrokke tyd binne die Romeinse wêreld, spesifiek in die area ter sprake. Onlangse navorsing toon aan dat dit slagspreuke was wat tot die Romeinse ryk se ideologie behoort het. Op propaganda vlak is daar luidkeels verklaar dat die Romeinse keiser die

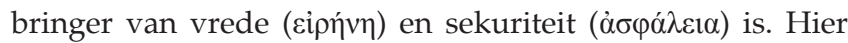
verklaar Paulus die teenoorgestelde - in direkte opposisie tot die status quo van die reeds bekende Romeinse imperiale ideologie en voorsienigheids-ideologie - 'an insult and mockery of Rome's imperial complacency' [sic] (Crossan \& Reed 2004:167). Jewett (1986) stem saam en argumenteer:

The Tessalonian style of honouring Roman benefaction was a distinctive adaptation of what Nilsson describes as the 'patriotic religion' of the earlier Greek polis that thanked the gods and the heroes for 'the personal freedom of her citizens and their selfesteem, the political rights which they exercised as members of the sovereign democracy, the blessings peace' ${ }^{\prime}$ and so forth. These ideals were co-opted in Thessalonica to legitimate Roman colonialism, and although the populace of Thessalonica had not experienced any form of democracy for centuries, the force of the ideals remained sufficiently alive to be useful at the propagandistic level. The goal of the imperial cult was to sustain Roman power, so the religious and political ideals it celebrated functioned as an ideology. The victims of this process of ideological co-optation were the economically disadvantaged, indigenous Greek population of Thessalonica - the very class of menial labourers and craftsmen from which the converts to the church were drawn. (pp. 124-125)

Paulus se missionêre boodskap kan dus gesien word as ' $n$ direkte uitdaging en teenstelling van die Romeinse Kyriargale imperiale magstrukture van sy dag (Crossan \& Reed 2004:141-142), geskryf aan diegene wat na alle waarskynlikheid nie diegene was wat die mag in die hande gehad het nie, maar eerder die gemarginaliseerdes op die periferie (Meeks 2003:73).

Die goeie nuus van die evangelie het in direkte opposisie gestaan tot die magsaansprake van Rome. Myns insiens was dit juis in hierdie radikale posisie waar die evangelie gewis in krag en volle oortuiging tot die gelowiges moes gekom het, deur die woorde en lewe van apostels wat die boodskap beliggaam het. ${ }^{17}$ Paulus en sy medewerkers was juis die geskikte persone vir die taak en die gemeente van Tessalonika 'n goeie voorbeeld van dit wat in daardie eerste missionêre gemeentes plaasgevind het en uiteindelik die ganse wêreld sou impakteer.

\section{Kyk ook Carter (2006:83-99).}

16.Vir ' $\mathrm{n}$ bespreking van die terme pax et securitas [vrede en sekuriteit] in die tyd van Augustus, kyk Vom Brocke (2001:167-185).

17.Kyk Malherbe (1987) wat ' $n$ baie goeie oorsig gee van die pastorale dimensie in Tessalonisense en die wyse waarop Paulus die gemeenskap pastoraal versorg het.

\section{Die evangelie wat in krag haar verskyning maak}

In 1 Tessalonisense 1:4 beklemtoon Paulus die feit dat hy seker is aangaande die Tessalonisense se uitverkiesing ( $\tau \dot{\eta} v$

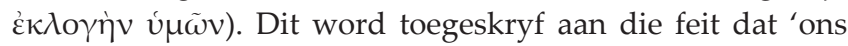
evangelie na julle gekom het nie net in woorde nie, maar ook in krag en in die Heilige Gees met volle oortuiging'

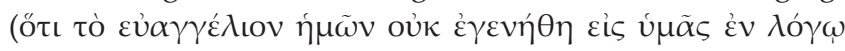

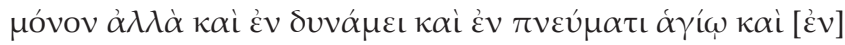
$\pi \lambda \eta$ фофофí $\alpha$ то $\lambda \lambda \tilde{\eta})$. Dit is interessant om daarop te let dat

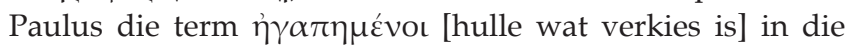
perfektum partisipium passief aanwend, met ander woorde dat die verkiesing van die Tessalonisense as ' $n$ voltooide werkwoord-aksie beskou kan word wat in die verlede plaasgevind het en ' $n$ bestaanstoestand tot gevolg gebring het wat tot in die hede (in verhouding tot die skrywer) voortgaan om te realiseer. Die fokus is met ander woorde nie soseer op die verlede aspek nie, maar op die huidige stand van sake wat resulteer uit die aksie uit die verlede, naamlik die feit van hulle verkiesing deur God as primêre handelende subjek en die konsekwensies daarvan (kyk Heiser 2005). Dit is verder interessant om daarop te let dat Paulus die ontvangs van die evangelie in krag en volle oortuiging in die passiewe werkwoordvorm غ̇ $\gamma \varepsilon v \eta \dot{\theta} \eta$ [het gekom] plaas (aoristos indikatief passief). ${ }^{18}$ Die kragtige wyse waarop die evangelie aan die Tessalonisense gekom het word uitgebeeld as iets wat God as handelende subjek in hulle midde gedoen het. Die kragtige werking daarvan is nie in die eerste plek ' $n$ resultaat van menslike handelinge en vermoë nie. Inteendeel, Paulus beklemtoon eerder sy eie swakheid en die feit dat hy vervolging beleef het in Filippi waarvandaan hy pas gevlug

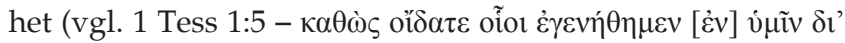
$\dot{v} \mu \tilde{\alpha} \varsigma$ en ook 2:2). ${ }^{19}$ Die implisiete magsdiskoers kom neer op die feit dat alhoewel Paulus in ' $n$ swak toestand by die Tessalonisense gearriveer het, God steeds kragtig aan die werk was. Dit dien dan ook as retoriese bewys dat God in en deur Paulus en sy medewerkers aan die werk was. Indien God kragtig in en deur hom aan die werk is, impliseer dit dat Paulus inderdaad 'n gestuurde van God is en met outoriteit en mag kan optree.

Paulus beskryf dat die gelowiges in Tessalonisense 180 grade omgedraai het, weg van die afgodsaanbidding na die ware en lewende God (1 Tess 1:9-10). Die aoristus indikatief aktief illustreer ook die feit dat dit nie in optatiewe of subjunktiewe wyse nie maar as feitlike gebeure plaasgevind het teen die tyd wat Paulus die brief geskryf het. Die feit dat die gelowiges weg gedraai het van afgodsaanbidding impliseer die wegbeweeg van ' $n$ bepaalde lewens-en geloofsoriëntasie na ' $n$ radikale ander oriëntasie. Die gelowiges het dus ' $n$ identiteitstransformasie ondergaan. Wanneer so 'n radikale lewensoriëntasie verander, word daar ' $n$ ander outoriteitshiërargie en simboliese universum in die proses geskep. God

18.Fee (1999:48) merk op dat 'the Spirit as the evidence of God's power at work in their midst is therefore presuppositional in Paul, and this usage sets the stage for our understanding of the Spirit as power and of Paul's use of "power" language as frequently an indirect reference to the Spirit.'

19.Ek stem saam met Fee (1999:45) dat die ' $k a i^{\prime}$ waarmee vers 6 begin verstaan moet word as ' $n$ 'coordinating conjunction'. Die benutting van parataxis, alhoewel vreemd by Paulus, mag hier bedoel gewees het waar die sinne intensioneel aan mekaar verbind word. 
se outoriteit en God se mag of krag word in die proses op 'n nuwe wyse geformuleer. Hierdie getransformeerde teologiese raamwerk resulteer dan in 'n nuwe wyse van nadenke oor God, die self, oor ander, die gemeenskap, die eindtyd en die etiek. Met ander woorde, wanneer 'n identiteitstransformasie plaasvind, verander teologie, antropologie, ekklesiologie, eskatologie en etiek. Ons kan dus argumenteer dat daar 'n fundamentele Begründungszusammenhang tussen hierdie terme bestaan, veral tussen identiteit en etiek (reëls) en etos (leefstyl).

\section{Paulus se beskrywing van implisiete missionêre identiteit}

Volgens Paulus word die gelowiges se bestaanstoestand gebaseer op die liefde en uitverkiesing deur God (Fee 1999:42). Hierdie nuwe identiteitsverstaan het geresulteer in 'n etos of leefstyl waar hulle nie net vir Paulus nie, maar ook

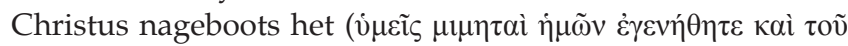
кupíov - 1:6). Die nabootsing word gekwalifiseer as dat die gelowiges die evangelie aanvaar het midde vele teenkanting,

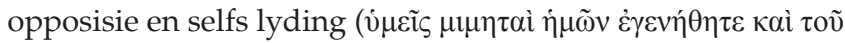

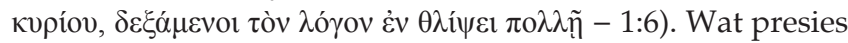
die aard van hierdie vervolging was, het geleerdes nie altyd duidelikheid oor nie (vgl. ook 1:6; 2:13-16; 3:2-4). Tog wil dit voorkom, indien mens deur die lens van magsdinamika kyk, of die Tessalonisense 'n vorm van Kyriosentriese dominerende mag beleef het wat óór hulle uitgeoefen is deur ' $n$ bepaalde groep wat ' $n$ verteenwoordiging was van ' $n$ bepaalde sosio-religieuse en/of -politieke sisteem. In die konteks van dominasie en mag wat óór individue of groepe uitgeoefen kan word, is daar ' $n$ paar reaksionele gedragsopsies. Die wat gedomineer word kan óf die gesag wat oor hulle uitgeoefen is verwerp en opponeer deur dominerende mag uit te oefen, óf hulle kan ondergeskik aan die betrokke mag word. Dit is interessant om daarop te let dat Paulus die grense van gedrag verskuif deur die reaksie van die gelowiges te beskryf as 'n reaksie met vreugde en

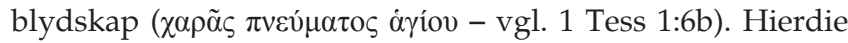
radikale etos word binne die konteks van die Gees se krag beskou wat ten spyte van die ervaring van dominasie reageer met gedrag wat getuig van bemagtiging. Die bron van hierdie bemagtiging is God se Gees en die motivering van hierdie gedragsreaksie vind plaas vanuit die dampkring van ' $n$ bepaalde verstaan van identiteit.

Volgens Fee (1999:46) kan die teologie van nabootsing in Paulus, wat aanspraak maak dat hy Christus naboots, beskou word as die hermeneutiese sleutel tot die etiese instruksies in die eerste missionêre gemeentes. Paulus het homself beskou as ' $n$ navolger en nabootser van Christus en het op sy beurt weer gelowiges gemotiveer en bemagtig om sy voorbeeld na te volg (1 Tess $2: 1-2,15 ; 3: 7)$ en sodoende opbouende voorbeelde vir mekaar te word (vgl. 1 Kor 1:11). In 1 Tessalonisense word dit duidelik dat vreugde realiseer in die konteks van lyding ${ }^{20}$ - met ander woorde, waar gelowiges gedomineer word deur eksterne magte en kragte, behou hulle die positiewe bemagtigende energie van

20. Hierdie tema kom ook in die res van die Nuwe Testament voor. Volgens 2 Korintiërs 8:2; Romeine 5:3-5; Handelinge 5:41; Jakobus 1:2. vreugde wat aan hulle geskenk word deur die Heilige Gees. Dit is baie interessant dat Paulus in 1 Tessalonisense 3:12 die gemeente oproep om toe te neem in liefde vir mekaar en liefde aan alle mense. Hier maan Paulus die gelowiges aan om liefdesdiens nie net aan die binne-groep of in-groep te betoon nie maar ook aan diegene wat buite die geloofsgemeenskap staan, of die uit-groep (vgl. ook Gal 6:10). Hiermee breek Paulus die sosiale stratifikasie en binêre polariteit wat in die Kyriargale denkraamwerk van die dag bestaan het. Wat sal die implisiete motivering daarvan wees, anders as 'n missionêre fokus, ' $n$ Christologies geïnformeerde (imago Christi) identiteitsverstaan waarvolgens gelowiges hulself as deelnemers beskou van die missio Dei - God se plan met die wêreld? Hierdie meta-narratief was implisiet in die vroeë Christelike denke en het as motiveringsbasis vir gedrag en leefwyse gefunksioneer. In die verwagting van die vroeë Christene se simboliese universum sou Christus binnekort terugkeer teen die agtergrond van hulle immanente eskatologiese verwagting. Paulus se motivering van die gelowiges om toe neem in liefde vir mekaar as geloofsgemeenskap en toe neem in liefde aan alle mense, word dan ook binne 'n doelsin konteks gestruktureer wat nou saamhang met die verwagting van die wederkoms (vgl. 1 Tess 3:13). Die wederkoms kan beskou word as die finale fase van die universele Goddelike missionêre narratief waarvolgens God sy Seun na die aarde gestuur het om te sterf, die Seun se terugkeer na die Vader en verhoging (Fil 2:5-10) en uiteindelik die finale wederkoms van die Seun. Binne die denkraamwerk en simboliese universum van die vroeë Christene het hierdie implisiete missionêre dimensie en makronarratief hulle identiteit en hulle etos of leefstyl beïnvloed.

\section{Paulus as voorbeeld in navolging van Christus}

Paulus was vir die eerste gelowiges in Tessalonika 'n persoon

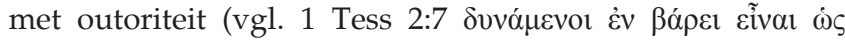

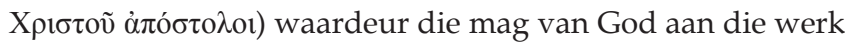
was te midde van vervolging, lyding en menslike swakheid. Alhoewel Paulus en sy medewerkers op hulle outoriteit as apostels kon aanspraak maak, het hulle eerder die Tessalonisense gedien en het nie hulle outoriteit gebruik of misbruik om hulle eie posisie en toestand te verbeter nie (vgl. Malherbe 1987). Inteendeel, hulle het nie hulself bemagtig nie maar gefokus op die bemagtiging van die gelowiges. Dit word veral duidelik in 'n stelling wat Paulus maak in ' $n$ konteks waar hy noem dat hy inderdaad op sy apostoliese posisie kon aanspraak maak om bepaalde resultate te bekom en sy mag aan te wend tot sy guns. Paulus sê dat hy nie sy mag op ' $n$ dominerende wyse aangewend het nie maar eerder liefdevol en sag met hulle gewerk het soos ' $n$ ma wat haar eie kinders vertroetel (1 Tess 2:7) (vgl. Malherbe 1987). Hierdie metafoor dien as anti-Kyriargale metafoor van diens. Paulus en sy medewerkers het nie aan hulle outoriteit vasgeklem nie, inteendeel! Hulle was selfs bereid om hulle eie lewens te gee tot voordeel van die gelowiges in Tessalonika - en hulle het dit gedoen met Geesgeïnspireerde blydskap (1 Tess 2:8). Soos ' $n$ vader teenoor sy eie kinders het hulle die gelowiges bemoedig en aangespoor (1 Tess 2:11). Paulus het dit vir 'n 
baie spesifieke rede gedoen, naamlik dat die gelowiges op die punt sou kom dat hulle tot eer van God sal leef (1 Tess

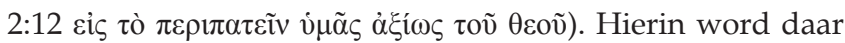
vir ons ' $n$ beeld geskets van Paulus wat die gelowiges wou bemagtig om selfstandig as geestelike mense te leef en so sy voorbeeld na te volg. Deur soos Paulus vreugde en blydskap uit te leef in die konteks van lyding en teenkanting, het die gelowiges as't ware die voorbeeld van Christus nagevolg. In die afsluitingsgedeelte van die brief gee Paulus 'n reeks imperatiewe waarvan die eerste is om altyd vreugdevol te wees (1 Tess 5:16-18). Vir Paulus is 'n vreugdevolle lewe 'n bewys van die Gees se kragtige werking in 'n gelowige se lewe en dit behoort ' $n$ kenmerkende etos van gelowiges te wees. Hierdie etos het ' $n$ bepaalde oorsprong wat gebaseer is op ' $n$ getransformeerde identiteit as synde mense wat geroep is om deel te wees van ' $n$ alternatiewe gemeenskap van gelowiges wat deel is van God se koninkryk (1 Tess 2:12

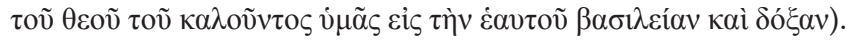
Die kragtige werking van God se gees en mag sal egter eers een die einde van die tyd in vervulling gaan. Die kragtige werking in hierdie bestaan is net ' $n$ voorsmaak van die realiteit wat gaan kom (vgl. ook Rom 14:17).

\section{Die magstryd teen ' $\mathrm{n}$ kosmiese agtergrond}

Die magstryd in Tessalonisense word teen ' $n$ kosmiese agtergrond geposisioneer. Op ' $\mathrm{n}$ makro spirituele vlak is daar minstens twee prominente magte aan die werk - God (en sy Gees) (1 Tess 1:6, 4:8; 5:19; 5:23) en Satan (1 Tess 2:18; vgl. ook 2 Tess 2:9). Die Gees van God bemagtig, bekragtig en versterk gelowiges (1 Tess 1:5; 5:8). Teenoor die Gees wat gelowiges bemagtig, vind ons die negatiewe mag van die Satan (vgl. 1 Tess 2:18 en 2 Tess 2:9) wat uitgebeeld word as die agent wat verantwoordelik is vir die feit dat Paulus nie sy geliefde broers en susters in die geloof kon besoek nie. In 1 Tessalonisense funksioneer Satan as ' $n$ agent van boosheid wat die mag het om moontlikhede te beperk en selfs sy mag te laat uitoefen op mense wat gelowiges skade berokken (vgl. 1 Tess 2:18). Die berokkening van skade kom neer op Kyriargale, dominerende, diskriminerende magsmisbruik. Hendriksen en Kistemaker (1953-2001) postuleer:

The fact as such that Satan exerts a powerful influence over the affairs of men, especially when they endeavour to promote the interests of the kingdom of God, is sufficiently clear from other passages (Job 1:6-12; Zech 3:1; cf. Daniel chapter 10). (p. 76)

Paulus wend 'familie-taal' aan om hierdie konsep uit te druk as hy in 1 Tessalonisense 5:5 die bestaan van twee opponerende families beskryf: die kinders (seuns) van die lig (

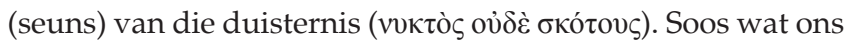
hier bo gesien het, bestaan daar ' $n$ onlosmaaklike verband tussen identiteit, etos en etiek. Diegene wat aan die nuwe familie van God behoort en deel uitmaak van sy koninkryk, lewe volgens die Gees en blus nie die Gees se kragtige

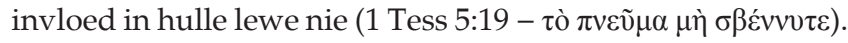
Die motivering vir hulle gedrag is gewortel in hulle identiteit en vloei voort vanuit hulle verhouding met God en status as kinders van God, lede van God se koninklike huishouding (1 Tess 2:12; vgl. ook 2 Tess 2:5). Diegene wat nie lewe volgens die wil van God nie, bevorder by implikasie nie die belange van God se koninkryk nie, maar eerder die magsbelange van die opposisie, Satan. In die tweede en latere brief aan die Tessalonisense sien ons ' $n$ duidelike ontwikkeling van hierdie denkpatroon:

Maar ons vra julle, broeders, met die oog op die wederkoms van onse Here Jesus Christus en ons vereniging met Hom, om nie gou julle verstand te verloor of verskrik te word nie - deur gees of deur woord of deur brief wat van ons afkomstig sou wees asof die dag van Christus al daar is. Laat niemand julle op enige manier mislei nie, want eers moet die afval kom en die mens van sonde geopenbaar word, die seun van die verderf die teëstander wat hom verhef bo al wat God genoem word of voorwerp van aanbidding is, sodat hy in die tempel van God as God sal sit en voorgee dat hy God is. Onthou julle nie dat ek dit altyd vir julle gesê het toe ek nog by julle was nie? En nou, julle weet wat hom teëhou, sodat hy op sy tyd geopenbaar kan word. Want die verborgenheid van die ongeregtigheid is al aan die werk, net totdat hy wat nou teëhou, uit die weg geruim is; en dan sal die ongeregtige geopenbaar word, hy wat die Here met die asem van sy mond sal verdelg en deur die verskyning van sy wederkoms tot niet sal maak, hy wie se koms is volgens die werking van die Satan met allerhande kragtige dade en tekens en wonders van die leuen en met allerhande verleiding van ongeregtigheid in die wat verlore gaan, omdat hulle die liefde tot die waarheid nie aangeneem het om gered te word nie. En daarom sal God hulle die krag van die dwaling stuur, om die leuen te glo, sodat almal geoordeel kan word wat die waarheid nie geglo het nie, maar behae gehad het in die ongeregtigheid. ${ }^{21}$ (2 Tess 2:1-12)

Dit is verder interessant om daarop te let dat daar in beide 1 en 2 Tessalonisense na die $\pi \alpha \rho o v \sigma i ́ a$ [wederkoms] verwys word in die onmiddellike konteks waar Paulus oor die mag van Satan praat. Hier word die woord nie in 'n nie-tegniese sin gebruik nie, by name om na God se teenwoordigheid te verwys nie (soos in 1 Kor 16:17; 2 Kor 10:10; Fil 1:26) maar eerder as verwysend na die tweede koms van Christus in glorie en majesteit, mag en krag (vgl. ook 1 Tess 3:13; 4:15; 5:23; 2 Tess 2:1, 8; Matt 24:3, 27, 37, 39; 1 Kor 15:23; Jak 5:7, 8; 2 Pet 1:16; 3:4, 12) (Hendriksen \& Kistemaker 1953-2001: 76-77). Die tweede koms word ook gekoppel aan oordeel, 'n moment waar God se absolute mag geopenbaar sal word. Dit behoort die gelowiges hoop te gee dat die absolute mag van God en geregtigheid van God aan hulle kant sal wees as die einde van die geskiedenis aanbreek.

\section{Die apostels se outoriteit, strategie en mag}

In die magsdinamiek van die brief se vermanende (paraenetiese) gedeelte is dit duidelik dat diegene wat Paulus se outoriteit verwerp nie bloot ' $n$ mens verwerp nie maar vir

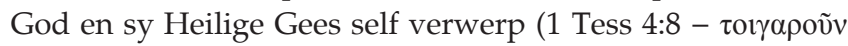

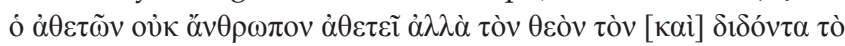

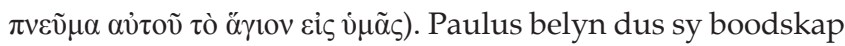
en gedrag met die wil van God (1 Tess 4:3; 5:18; vgl. ook die Deutero Pauliniese 2 Tim 1:1) en by implikasie met die makro magsdinamika wat hier bo bespreek is. Dit is ' $n$ geweldige sterk uitspraak wat Paulus hier maak met betrekking tot 21.Afrikaanse ou vertaling, Bybelgenootskap van Suid-Afrika, 1953. 
die sosiale magsdinamika (asimmetriese magsdinamika) en sy posisie binne die geloofsgemeenskap. Dit behels by implikasie dat diegene wat Paulus se boodskap en outoriteit verwerp hulself nie met die wil van God belyn nie maar met die wil van Satan. Deur hulle karakter en gedrag, aanvaarding of verwerping van Paulus, toon hulle self aan of hulle kinders van die lig of kinders van die duisternis is en aan watter kant van die kosmiese magstryd hulle behoort (1 Tess 4:7). Paulus wend retoriese vaardighede aan om appèl te maak op die gelowiges om van alle immoraliteit weg te bly en motiveer hulle inter alia deur die implikasie

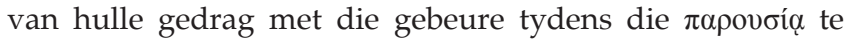
verbind wanneer Christus in sy volle glorie, outoriteit en mag sal verskyn (vgl. 1 Tess 5:1-11; 23). Diegene wat hierdie onderwysing verwerp posisioneer hulself binne die konteks van die magstryd aan die kant van Satan.

Diebasiese saak kom dus neer op ‘n bepaalde lewensoriëntasie en verstaan van identiteit. Gelowiges is geroep en uitverkies deur God teen die agtergrond van die missio Dei, opsy geplaas deur Hom, en by implikasie binne die konteks van 'n alternatiewe sfeer van mag geplaas (die mag van die lig). Die bewys van ' $n$ lewe in die dampkring van die lig is vreugde soos hier bo genoem is, en 'n lewe wat van 'n hoë etiese vlak getuig en toenemend groei en ontwikkel (1 Tess 3:12-13 -

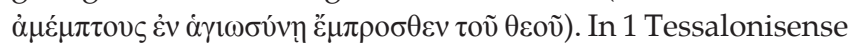
4:1-12 sien ons dat Paulus se siening van die etiese lewe fundamenteel geïntegreerd staan met die aspek en proses van gemeenskapsvorming en gemeenskapsonderhouding (Gaventa 1998:60). Ons liggame, argumenteer Paulus, behoort nie aan ons self nie, maar aan God. Die implikasie is dat ons nie self die mag, outoriteit en vryheid het om met ons liggame te maak soos ons wil nie. Ons gedrag behoort beheer en gekontroleer te word, ondergeskik gemaak te word aan die mag en outoriteit van God (vgl. ook 1 Kor 5:19), die Koning en hoof van die familie. Gelowiges is hoogstens aanspreeklik teenoor God en verplig om te doen wat God tevrede maak (Gaventa 1998:61).

In 'n wêreld van religieuse kultusse en seksuele immoraliteit sal die gelowige se kenmerkendheid daaruit bestaan dat hy of sy disassosieer van daardie bestaanstoestand en gedrag (heiligheid - 1 Tess 4:7 $\dot{\alpha} \gamma(\alpha \sigma \mu \tilde{\omega})$. Hierdie radikale lewenswyse met die hoë etiese uitwerking getuig dan op haar beurt weer van die krag van God se Gees wat aan die werk is in die gelowiges wat op grond van die feit dat hulle

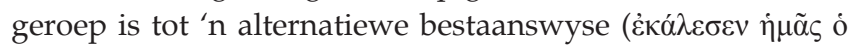
$\theta \varepsilon o ̀ \varsigma)$ vanuit $\alpha \kappa \alpha \theta \alpha \rho \sigma i ́ \alpha$ [onreinheid] ter wille van heiligheid

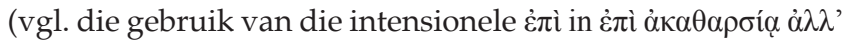
$\dot{\varepsilon} v \dot{\alpha} \gamma(\alpha \sigma \mu \tilde{\varphi})$. Alle gelowiges het die geskenk van God se Gees ontvang wat op sy beurt weer die karakter van God in hulle sal reproduseer (Fee 1999:51). Deur die aanwending van

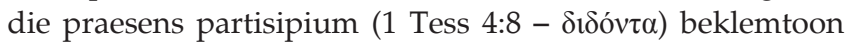
Paulus die toenemende en permanente aktiwiteit van God se Gees en die geassosieerde mag wat sal resulteer in die vermoë van gelowiges om hulle eie liggame te beheer in die konteks van heiligheid (1 Tess 4:4) en onderskeidingsvermoë.

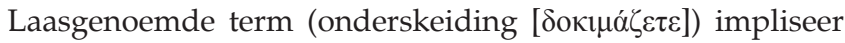
' $n$ bemagtigende dimensie en vermoë om te kan kies en nie 'n slagoffer te wees van die mag van die duisternis nie. Dit word duidelik indien die parallelistiese struktuur van 1 Tessalonisense 5:19-22 in ag geneem word (kyk Figuur 1).

Die eerste imperatief in die reeks fokus op die Gees en gelowiges en word aangemoedig om nie die werk en manifestering van die Gees te blus nie. Dit word verder gekwalifiseer as synde nie profesie gering te skat nie. Die vermoë om te kan toets, evalueer en te onderskei veronderstel niks minder nie as die vermoë tot bemagtiging. Die vraag is egter hoe hierdie onderskeidingsvermoë plaasvind en aan die hand van watter kriteria? Volgens Fee (1999:61) is dit duidelik uit 2 Tessalonisense 2:2 en 2 Tessalonisense 2:15 dat valse profesieë en leringe in die eerste missionêre geloofsgemeenskappe bestaan het, soos in die geval van die misverstand rondom die aanbreek van die wederkoms. In 2 Tessalonisense bemoedig die skrywer die gelowiges deur hulle te motiveer om 'vas te hou aan die tradisies of oorleweringe wat aan hulle geleer is' (kyk egter Van Aarde 2000). Dit maak dit duidelik dat daar ' $n$ interne lokus van kontrole ingebou is wat gebaseer was op ' $n$ bepaalde oorgelewerde verstaan van die Christusgebeure en die inhoud van die evangelie. Die gelowiges word aangemoedig om vas te hou aan dít wat goed is - en dit wat goed is, word gevind binne die raamwerk van die oorgelewerde tradisie (kyk 1 Kor 14:20-25) (Fee 1999:61).

\section{Bemagtigende voorbeelde van geloof}

Volgens Paulus se openingswoorde in die eksordium van die brief (1 Tess 1:6-8) het die gelowiges die voorbeeld van Paulus en Christus nagevolg deur die geloof midde vervolging met

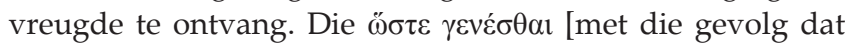
julle geword het] grammatikale konstruksie gee die resultaat van eersgenoemde, naamlik dat die gelowiges uiteindelik

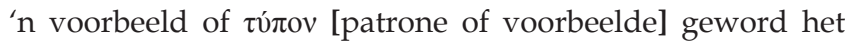
vir al die gelowiges in Macedonië en Agaie. Paulus gebruik vervolgens die perfektum passief vorm van die werkwoord

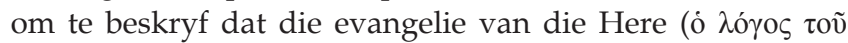

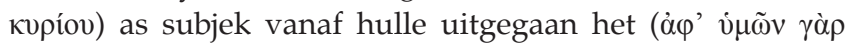
$\dot{\varepsilon} \xi \eta ́ \chi \eta \tau \alpha l)$ en dat dit 'n kragtige uitwerking en missionêre getuienis na almal buite die spesifieke geloofsgemeenskap se

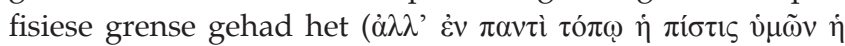

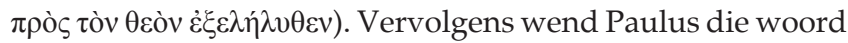
$̋ \sigma \tau \varepsilon$ [sodat of met die gevolg dat] aan waarin hy ' $n$ doelsin vorm wat uit die voorafgaande voortvloei, naamlik dat dit die kragtige werking van hierdie missionêre getuienis en aktiwiteit van die Gees was dat Paulus geensins nodig gehad

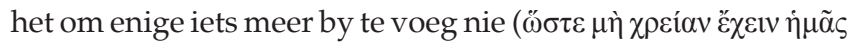

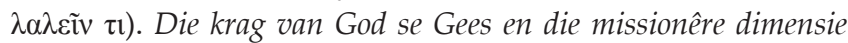

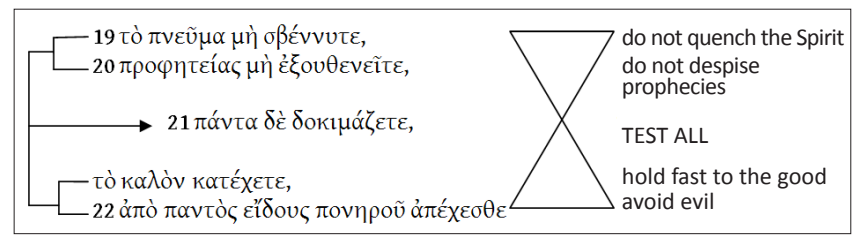

Bron: Fee, G., 1999, God's empowering presence, Hendrickson, Sterling, MA.

FIGUUR 1: 1 Tessalonisense 5:19-22. 
daarvan, lê nie net in die hande van een of twee apostels nie, maar in die hande van God se Gees wat in en deur die liggaam van Christus werk, selfs deur gewone gelowiges wat nie die amptelike magstitels dra nie. In hierdie vroeë Pauliniese brief vind ons duidelike bewys van ' $n$ 'primitiewe' (of vroeë) verstaan van die missionêre dimensie in die eerste gemeentes. In hierdie missionêre dimensie is God en sy krag of mag aan die werk in die wêreld (vgl. die missio Dei konsep). Dit is die Gees van God wat gelowiges bemagtig en opneem in die kragveld van die missio Dei. Dit is nie die werk van individuele persone in menslike magsposisies nie. Juis om hierdie rede is dit nie vreemd nie dat Paulus die kerklike geskiedenis binnekom as deel van ' $\mathrm{n}$ dinamiese span op grond van die implisiete bewuswording van die feit dat dit God se Gees is wat in en deur hom aan die werk is. Net so werk God kragtig in en deur ander - selfs in heidene - die wat voorheen uitgesluit was uit die binnekring van God se verbondsverhouding met Israel.

Hier onder gaan daar geargumenteer word dat waar Paulus wel die asimmetriese 'power-over' strategie aangewend het, was die doel daarmee om gelowiges te bemagtig tot geestelike volwassenheid en selfstandigheid. Daar sal aangetoon word hoe Paulus paternalistiese 'power-over' taal aanwend tot voordeel van die ontwikkeling en bemagtiging van die afhanklike partye en ' $n$ transformatiewe dimensie impliseer. Hierdie proses behoort dan te kulmineer in ' $n$ situasie waar die 'power-over' kategorie getransformeer kan word in ' $n$ situasie waar hierdie vorm van mag nie meer nodig sal wees nie maar ' $n$ ander karakter sal aanneem (kyk Ehrensperger 2007:28) - daar waar gelowiges opgeneem sal word in die missio Dei en self missionêre agente sal word.

\section{Paulus as deel van ' $n$ dinamiese span}

Paulus was 'n man van mag, maar alles behalwe 'n 'lone ranger' op sy eie missie, alhoewel baie mense daardie idee van Paulus mag hê. Die meeste mense, indien hulle aan Paulus dink, sien 'n onafhanklike gedrewe individu op 'n missie wat tot die uiterstes sal gaan om die doel te bereik. Ehrensperger (2007:35) argumenteer oortuigend dat Paulus se missionêre reise en briewe nie die uitsluitlike produk van ' $\mathrm{n}$ individu is nie maar die produk van ' $\mathrm{n}$ dinamiese span en dus ' $n$ korporatiewe onderneming is. Die vroeë Christusbeweging het deel uitgemaak van 'n noue netwerk van medewerkers. Selfs voor Paulus tot bekering gekom het, het die netwerk van gelowiges reeds bestaan (vgl. Gal 1:17). 1 Tessalonisense is ' $n$ goeie illustrasie van die punt. Die brief is nie deur Paulus alleen geskryf nie, maar 'n brief wat deur Paulus, Silvanus en Timoteus (1 Tess 1:1) geskryf is, wat die korporatiewe dimensie van die vroegste Christus beweging illustreer (Ehrensperger 2007:38). Reeds van die heel begin af was Paulus deel van ' $n$ span apostels (1 Tess 2:7; 5:24). In 1 Tessalonisense word die eerste persoon meervoud verskeie kere aangewend, byvoorbeeld

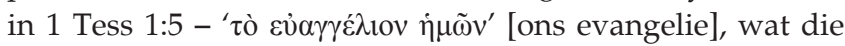
korporatiewe dimensie uitdruk en nie die missie van een of ander 'lone ranger' nie. Die vroegste Christusbeweging se missie was ' $n$ korporatiewe aangeleentheid wat deur verskeie persone gedeel is (Ehrensperger 2007:40). Verder beklemtoon dit dat daar nie ' $n$ dominerende asimmetriese verhouding tussen Paulus, Silvanus en Timoteus bestaan het nie maar eerder een van gelykheid en spanwerk (Lietaert Peerbolte 2003:228-233). Ehrensperger (2007:47) is korrek as sy opmerk: 'It should thus come as no surprise that a variety of people who are performing multiplicity of tasks within the movement can be called sunergoi.' In 1 Korintiërs 16:16

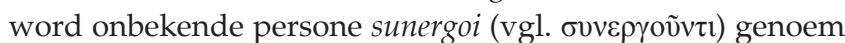
en Paulus moedig die geloofsgemeenskap in Korinte aan om ondergeskik aan hierdie leiers te wees. Teen die agtergrond van die magsdinamika in Paulus is dit belangrik om daarop te let dat alhoewel dit mag voorkom of daar 'n asimmetriese magsverhouding bestaan, deel Paulus en sy medewerkers die feit dat hulle almal opgeneem is in die kragveld van die Gees en dat hulle almal ondersgekik is aan God, medewerkers wat nie in die eerste plek ondergeskik is aan mekaar nie maar aan God. Ehrensperger (2007) stem hiermee saam en stel dit treffend:

A sunergos is a co-worker because he/she is involved in the work of the proclamation of the gospel as is Paul. [T] he noun therefore stresses the cooperative rather than the hierarchical dimension of the relationship between those designated sunergoi and Paul, who is one amongst them. ${ }^{22}$ (pp. 47-48)

Lietaert Peerbolte (2003:231) is van mening dat die sunergoi gewoon Paulus se assistente was, terwyl Ollrog (1979:72) en Ehrensperger (2007:48) van mening is dat die sunergoi nie net assistente van Paulus was en hom in sy missionêre taak ondersteun het nie, maar volwaardige bemagtigde medewerkers was wat selfstandig missionêr te werk kon gaan. Miskien lê die misverstand daarin dat Paulus self die term nie altyd op dieselfde wyse aanwend nie. Dit ondersteun die tese van Ehrensperger (contra Lietaert Peerbolte 2003:231) dat die term nie teen daardie tyd alreeds as ' $n$ tegniese term gefunksioneer het nie (Reinbold 2000:213-224).

Paulus se fakultatiewe (nie verpligte, uit vrye keuse) gebruik van familiale taal (kinship language) in 1 Tessalonisense 3:2 en elders versterk die argument dat Paulus nie altyd in asimmetriese hiërargiese lyne van outoriteit gedink het nie maar eerder familiale terme gebruik op ' $n$ wyse dat ' $n$ beeld geskep word van 'n gemeenskap van prinsipiële simmetriese verhoudings. Binne die raamwerk van hierdie simmetriese simboliese universum van familiale taal het sommige lede wel bepaalde leierskapsfunksies en mag op 'n betrokke moment in tyd ' $n$ bepaalde vorm van outoriteit in die geloofsgemeenskap of beweging uitgeoefen. Dit wil tog voorkom of Paulus as dominante figuur in sommige gevalle sy medewerkers uitstuur om bepaalde funksies te vervul (bv. vir Timoteus). Op 'n funksionele vlak het daar dus 'n asimmetriese magsdinamika op mentor verhoudingsvlak in sommige kontekste bestaan. Daar moet myns insiens egter in gedagte gehou word dat die aard van mag dinamies en veranderlik is (Ehrensperger 2007:54) en dat daar onderskei moet word tussen funksionele situasiegebonde

22. Lietaert Peerbolte $(2003.231)$ argumenteer dat sunergoi gewoon verwys na Paulus se assistente, terwyl Ollrog (1979:72) en Ehrensperger (2007:48) die sunergoi nie net beskou as assistente wat Paulus gehelp het in sy eie sendingplanne en nie net beskou as assistente wat Paulus gehelp het in sy eie sendingplanne en
subjektiewe behoeftes nie maar self bemagtig was en volledig missionêr kon funksioneer. 
magsverhoudinge en prinsipiële magsposisies by Paulus. Op 'n prinsipiële vlak bestaan daar ' $n$ simmetriese en gelyke magsverhouding tussen gelowiges. Paulus se aanwending van funksionele asimmetriese magsverhoudinge, soos hier bo geargumenteer dien ' $n$ bepaalde funksie, naamlik om gelowiges te bemagtig om uiteindelik onafhanklike broers en susters in die geloof te wees (vgl. 1 Kor 3:2; kyk ook 1 Pet 2:2). In 1 Tessalonisense word beide Silvanus en Timoteus uitgebeeld as medewerkers wat op gelyke vlak met Paulus funksioneer (1 Tess 2:6 en 2 Kor 1:19). Om kortliks saam te vat: Daar kan dus geargumenteer word dat die magsdinamika in Paulus dinamies daarna uitgesien het na aanleiding van die kontekstuele situasie en nie bloot staties van aard was nie en dat daar onderskei moet word tussen magsdinamiese verhoudinge op ' $n$ funksionele en prinsipiële vlak (Aasgaard 2004:287).

Paulus en sy medewerkers het onder andere deur middel van briewe met bepaalde geloofsgemeenskappe gekommunikeer wat die fisiese kontak tussen hulle vervang het. In 1 Tessalonisense 5:26 wend Paulus die imperatief vorm van die werkwoord aan en gee die opdrag dat die brief wat hy geskryf het aan die hele geloofsgemeenskap hardop gelees

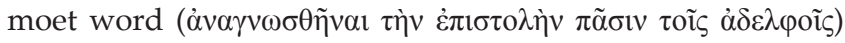
(Aland et al. 1993:538). Dit bewys ' $\mathrm{n}$ bepaalde vorm van outoriteit en mag wat fakultatief deur die geloofsgemeenskap aanvaar moes word. Hierdie vorm van mag kan alleen funksioneer indien die groepslede die outoriteit aanvaar en die asimmetriese magsdinamika in stand hou. Die geskrewe brief vorm deel van 'n kommunikasieproses en is nie die kommunikasie nie tussen Paulus en die gemeentes aan wie hy skryf nie. Die geskrif kan dus nie beskou word as die magsvolle kommunikasie strategie van een individu nie, maar die voortgaande gesprek tussen groepe (Ehrensperger 2007:56). Dit word veral duidelik in 1 Tessalonisense waar Paulus nie die enigste persoon is wat kommunikeer nie maar deel uitmaak van 'n span waarvan hy die medeskrywer

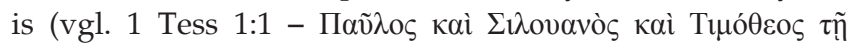

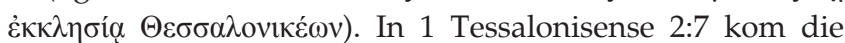
implisiete funksionele asimmetriese magsdinamika na vore as Paulus aan die geloofsgemeenskap noem dat hy wel aanspraak kon maak op die mag en outoriteit wat hulle as

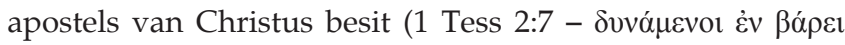

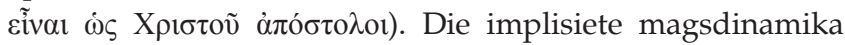
wat hier na vore kom, is dat daar binne die sosiale konteks van die geloofsgemeenskap in 1 Tessalonisense wel ' $n$ asimmetriese hiërargiese magstruktuur bestaan het en deur die verskillende partye erken was. Die geloofsgemeenskap het baie goed geweet dat Paulus oor bepaalde gesag en outoriteit beskik. Die noodwendige verwagting is dat Paulus die mag sou uitoefen. Tog maak Paulus dit duidelik dat hy juis nie sy magsvolle posisie gebruik het om sy eie voordeel te trek en homself verder in die proses te bemagtig nie. In 1 Tessalonisense 2:7 gebruik Paulus die metafoor van 'n ma wat haar kinders liefdevol en sag hanteer. Net so sou Paulus sy eie lewe vir die geloofsgemeenskap gee. Hier keer Paulus die hiërargies asimmetriese magsdinamika op sy kop en beklemtoon die Christelike etos van selfopofferende liefde. Dit herinner die pauliniese leser aan Filippense 2:5-10 waar Paulus die geloofsgemeenskap in Filippi aanmoedig om dieselfde etos as Christus te hê wat homself leeg gemaak en gegee het ter wille van ander en tot hulle voordeel. Deur jouself fakultatief op hierdie wyse te gee aan iemand anders word die gewer in 'n broos posisie gelaat allermins in ' $n$ posisie van mag en dominasie geplaas omdat mag by wyse van spreke weggegee word (1 Tess 3:12). Die onderliggende motivering in hierdie konteks is duidelik die liefde in navolging van Christus (Fil 2:5-10; Joh 3:16). Binne die dampkring van die Christelike etiek word negatiewe dominerende mag oor iemand anders dus beskou as synde uit lyn met die fundamentele selfverstaan van die Christendom. Binne die Christendom behoort mag ter wille van ander aangewend te word. Mag behoort weggegee te word ten einde ander te bemagtig. Die basiese motivering vir Paulus is gebaseer op die genade van God - genade (en die diskoers van genade) as die middelpunt en leitmotif van Paulus se teologie word gemotiveer deur selfopofferende liefde ter wille van ander se groei en ontwikkeling (Ehrensperger 2007:63; kyk ook Polaski 1999:105-107; Joubert 2000; Harrison 2003:212-213). In 1 Tessalonisense, soos hier bo genoem, stel Paulus dit in 3:12 duidelik dat hierdie liefde nie net getoon word aan die wat aan die in-groep behoort nie, maar ook aan die wat aan die buite-groep behoort, wat 'n duidelike missionêre gerigtheid na binne en na buite impliseer. Hierdie liefdesgerigtheid is missionêr omdat die motivering daarvan binne die dampkring van die missionêre teologie en Christologie verstaan word en aangesien dit as die implisiete motivering van die gedrag van die gelowige dien.

\section{Genade as leitmotif en die implikasie daarvan vir die magsdiskoers in Paulus}

Alhoewel Dickson (2003:228) en Ehrensperger (2007:46) korrek is as hulle betoog dat Paulus en sy navolgers onderskei het tussen 'gewone' gelowiges en diegene wat tot ' $n$ spesifieke taak afgesonder is, stem ek nie saam dat die missionêre dimensie uitsluitlik begin en geëindig het met spesifieke persone nie. Hier bo het ons alreeds aangetoon hoe God se Gees aan die werk is in en deur 'gewone' gelowiges en hoe hulle opgeneem word in die missio Dei, of God se sending missie waar God en sy Gees die primêre handelende subjekte in die missionêre dimensie is. In die proses waar ' $\mathrm{n}$ missionêre beweging tot stand kom is dit logies dat sommige individue aanvanklik uitgesonder sou word vir die missionêre uitbreiding van die beweging. Paulus en sy medewerkers was juis dit. Paulus het geglo dat hy spesifiek deur God geroep was vir hierdie taak (Gal 1:11) - die uitbreiding van die evangelie na die nasies. Dit beteken egter nie dat die missionêre dimensie begin en eindig met Paulus nie. Die missionêre dimensie behoort nie aan Paulus nie en ook nie aan sy medewerkers en voorgangers nie, maar aan God wat deur sy Gees magtige of kragtige werkinge verrig en gelowiges bemagtig om die evangelie uit te dra en die evangelie te praktiseer, inter alia in die vorm van liefde na binne die geloofsgemeenskap maar ook aan alle mense (1 Tess 3:12). Die Gees dra die volmag om te besluit aan wie hy gawes skenk (vgl. 1 Kor 12), insluitende die missionêre dimensie wat wesenlik tot die evangelie behoort en altyd implisiet teenwoordig is. 
Die aksielyn van genade en liefde in Paulus vloei altyd in 'n missionêre rigting - van God na Christus en van daar na apostels en gelowiges. Dit is dus belangrik om daarop te let dat Christelike liefde en genade nie eindig en stol in die konteks van die geloofsgemeenskap nie, maar altyd weer gerig behoort te wees aan die wat buite die geloofsgemeenskap is (1 Tess 3:12). In Galasiërs 6:10 is dit duidelik dat Paulus die geloofsgemeenskap daar ook aanmoedig om die goeie te doen aan alle mense, veral maar geensins eksklusief gesproke aan die wat binne die ekklesia is nie. Op so 'n wyse gebruik gelowiges die genade en mag wat aan hulle gegee is om die goeie te doen en ' $n$ positiewe bemagtigende verskil te maak in 'n Kyriargale wêreld van min liefde en min genade - 'n gepaste respons op die genade geïnisieer deur God self (Ehrensperger 2007:64, 69, 78). ${ }^{23}$ In 1 Tessalonisense 3:12 wend Paulus die optatiewe vorm van die werkwoord aan om die

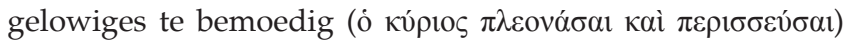
om toe te laat dat die Here hulle liefde vir mekaar sal laat

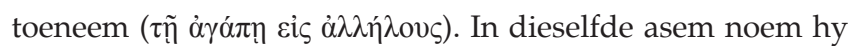
dat hierdie liefdesgerigtheid nie net gerig moet wees aan diegene binne die geloofsgemeenskap nie, maar ook aan die

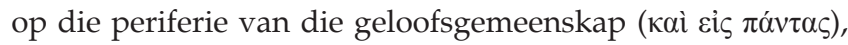
net soos wat die apostels ook aan hulle liefde bewys het

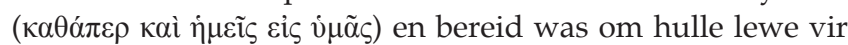
die geloofsgemeenskap af te lê. Op verskeie ander plekke beklemtoon Paulus die feit dat die etiese lewe en opbouende aspek van die Christelike lewe gemotiveer deur liefde, nie net gerig moet wees aan die wat aan die in-groep behoort nie, maar ook aan die buite die Christelike gemeenskapsgrense. So merk Paulus byvoorbeeld in 1 Tessalonisense 4:12 op dat die gelowiges 'n eerbare lewe moet lei wat die agting van die mense buite die gemeente afdwing (iv $\alpha \pi \varepsilon \rho ı \alpha \tau \tilde{\tau} \tau \varepsilon \varepsilon v j \sigma \chi \eta \mu o ́ v \omega \varsigma$

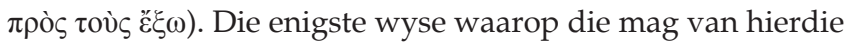

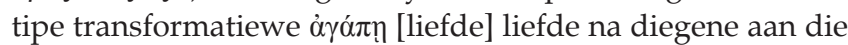
buitekant uitgeleef kan word, is vanuit ' $n$ bepaalde identiteit, etos en implisiete etiek en binne die raamwerk van die missionêre plan van God en sy Koninkryk.

\section{Samevatting}

In hierdie artikel is daar geargumenteer dat daar in 1 Tessalonisense ' $n$ interessante verband bestaan tussen mag, die missionêre dimensie en die etiek. Die begronding van die evangelie vind sy oorsprong in die missio Dei - die genadige missionêre plan van God wat sy Seun gestuur het om vir die mensdom te sterf, wat opgestaan het uit die dood, en uiteindelik weer na die kosmos sal terugkeer. Teen die agtergrond van die missio Dei speel 'n kosmiese magstryd af tussen God en Satan. Die uiteindelike uitkoms van die magstryd is alreeds duidelik teen 'n eskatologiese agtergrond en verwagting dat Christus sal terugkeer as oorwinnaar. Intussen beleef mense steeds iets van die kosmiese magstryd op die strydveld van die aarde. Daar is twee opponerende magsgroepe of families wat aan twee koninkryke behoort,

23.Ehrensperger (2007:70) wys op die volgende: '[T]here exists a difference between reciprocity and mutuality. In the Graeco-Roman context, patronage implied that reciprocity and mutuality. In the Graeco-Roman context, patronage implied that lower-ranked clients became dependant on their patrons and that it was all about the enhancement of the status and power of the patron. In contrast to the typical values of Roman society Paul encourages a relationship of mutuality where all parties are edified. God was the initiating subject who showed grace. Believers show grace towards others (mutuality), extending the grace they have received out of mutual concern for one another.' naamlik die kinders van die lig en die kinders van die duisternis. Beide groepe het 'n bepaalde agenda en werk teen mekaar se magsbelange. God roep apostels, diegene wat gestuur is met outoriteit en mag deur wie God se Gees aan die werk is om die evangelie en die praktiese boodskap daarvan uit te dra én in nabootsing van Christus uit te leef. Die mag wat die apostels het, is egter mag wat aan hulle geskenk is en die doel daarvan is om gelowiges te bemagtig om self ook selfstandige missionêre agente te wees - 'n bewys dat God se Gees self ook aktief in en deur hulle werk. Paulus beklemtoon hierdie element as hy verwys na die kragtige wyse waarop die evangelie tot die Tessalonisense gekom het ten spyte van Paulus se eie brose toestand.

Die kinders van die lig handhaaf 'n hoë etiese lewensstyl wat vanuit hulle identiteit as kinders van God voortvloei. Hulle ontvang krag van God om met vreugde te leef midde tye van swaarkry en bewys selfopofferende liefde in voorbeeld van Christus. Hierdie missionêre liefdesgerigtheid is nie net bedoel om gerig te wees aan die aan die binnekring nie, maar ook bedoel om missionêr na buite gerig te wees ten einde ander positief te beïnvloed deur liefdesdiens. Deur die apostels se voorbeeld na te volg, mag die gelowiges selfs voorbeelde vir ander word en sodoende bemagtigend opgeneem word in die kragtige missionêre plan van God en ander beïnvloed om deel te word van God se magtige koninkryk van lig.

Ten slotte, indien die missionêre gerigtheid in Tessalonisense verstaan word as bemagtigende liefdesdiens in navolging van Christus teen die agtergrond van die missio Dei, dan word die definisie van sending nie beperk tot Kyriargale propaganda nie, maar verhelderend uitgebrei tot antiKyriargale, ruimte-skeppende, bemagtigende liefdesdiens aan diegene binne én buite die geloofsfamilie. Volgens Stark (1996) se sosiologiese navorsing rondom die eksponensiële groei van die Christendom in die eerste drie eeue, was dit juis die vroeë Christene se vermoë om liefdesdiens aan mekaar én die heidene te bewys in kontekste van krisis, hongersnood en pandemies, asook die feit dat vrouens 'n belangrike rol gespeel het, wat gelei het tot die Christendom se aansienlike groei. Myns insiens staan die kerk voor die uitdaging om hierdie anti-Kyriargale dimensie van sending as liefdesdiens te herontdek, veral waar die kerk al meer op die periferie van die samelewing beweeg (Dekker 2011). Die geskiedenis van die vroeë kerk leer ons dat dit juis in hierdie kontekste van liminaliteit is waar die kerk haar ware missionêre identiteit herontdek.

\section{Erkenning Mededingende belange}

Hierdie navorsing is gedoen terwyl prof. Kobus Kok aan die Radboud Universiteit, Nijmegen, Nederland studeer het, wat moontlik gemaak is deur ' $\mathrm{n}$ doktorale beurs van die Radboud Universiteit, Nijmegen en 'n Navorsings- en Ontwikkelingsbeurs deur die Universiteit van Pretoria, SuidAfrika. 


\section{Literatuurverwysings}

Aasgaard, R., 2004, My beloved brothers and sisters: Christian siblingship in Paul, T\&T Clark, London, New York.

Aland, B., Aland, K., Black, M., Martini, C.M., Metzger, B. M. \& Wilgren, A., 1993, The Greek New Testament, 4th edn., United Bible Societies, Münster.

Allen, A. 1999, 'Solidarity after identity politics: Hannah Arendt and the power of feminist theory', Philosophy and social Criticism 25(1), 97-118. http://dx.doi. org/10.1177/019145379902500105

Baltrusch, E., 2002, Die Juden und das Römische Reich: Geschichte einer konfliktreichen Beziehung, Wissenschaftliche Buchgesellschaft, Darmstadt.

Blight, R., 1989, An exegetical summary of 1 \& 2 Thessalonians, Summer Institute of Linguistics, Dallas.

Bourdieu, P., 1991, Language and symbolic power, Polity Press, Malden.

Carter, W., 2006, The Roman Empire and New Testament Studies: An essential guide, Abingdon Press, Nashville.

Crossan, J. \& Reed, J., 2004, In search of Paul, Harper, New York.

Dekker, W., 2011, Marginaal en missionêr: Kleine theologie voor een krimpende kerk Uitgeverij Boekencentrum, Zoetermeer.

Dickson, J.P., 2003, Mission-commitment in ancient Judaism and in the Pauline communities, Mohr Siebeck, Tübingen.

Ehrensperger, K., 2007, Paul and the Dynamics of Power, T\&T Clark, New York.

Fee, G., 1999, God's empowering presence, Hendrickson, Sterling, MA.

Gaventa, B., 1998, First and second Thessalonians, John Knox Press, Louisville.

Harrison, J.R., 2003, Paul's language of grace in its Graeco-Roman context, Mohr Siebeck, Tübingen.

Heiser, M.S., 2005, Glossary of morpho-syntactic database terminology, Logos Bible Software, Bellingham.

Hendriksen, W. \& Kistemaker, S.J., 1953-2001, New Testament commentary: Exposition of I-ll Thessalonians, Baker Book House, Grand Rapids. (New Testament Commentary, vol. 3[76]).

Hengel, M., 2003, Acts and the history of earliest Christianity, Wipf \& Stock Publishers, Eugene, OR.

Holmberg, B., 1978, Paul and power: The structure of authority in the primitive church as reflected in the Pauline epistles, Gleerup, Lund.

Horsley, R.A., 1997, Paul and empire: Religion and power in Roman imperial society, Trinity Press International, Harrrisburg, PA.

Horsley, R.A., 2004, Paul and the Roman imperial order, Trinity Press, International, Harrisburg, PA.
Jewett, R., 1986, The Thessalonian correspondence, Fortress Press, Philadelphia.

Joubert, S.J., 2000, Paul as Benefactor: Reciprocity, strategy and theological reflection in Paul's collection, Mohr Siebeck, Tübingen.

Kok, J., 2010, 'Die rol van die etiek in die prediking: Nuwe navorsing in Nuwe Testamentiese etiek en die implikasie daarvan vir die prediking, Verbum et Ecclesia 31(1), Art. \#375, 10 pages. http://dx.doi.org/10.4102/ve.v31i1.375

Lietaert Peerbolte, L.J., 2003, Paul the missionary, Peeters, Leuven.

Malherbe, A.J., 1987, Paul and the Thessalonians: The philosophic tradition of pastora care, Fortress, Philadelphia.

Meeks, W., 1993, The origins of Christian morality, Yale University Press, New Haven.

Meeks, W., 2003, The first urban Christians: The social world of the Apostle Paul, Yale University Press, New Havan.

Ter Borg, M.B. \& Van Henten, J.W. (eds.), 2010, Powers: Religion as a social and spiritual force, Fordham University Press, Fordham.

Nasrallah, L. \& Schüssler Fiorenza, E. (eds.), 2009, Prejudice and Christian beginnings: Investigating race, gender and ethnicity in early Christian studies, Fortress, Minneapolis.

Ollrog, W.H., 1979, Paulus und seine Mitarbeiter: Untersuchungen zu Theorie und Praxis der Paulinischen Mission, Neukirchener, Neukirchen.

Polaski, S.H., 1999, Paul and the discourse of power, Sheffield Academic Press, Sheffield.

Reinbold, W., 2000, Propaganda und Mission im ältesten Christentum: Eine Untersuchung zu den altesten Modalitäten der Ausbreitung der frühen Kirche, Vandenhoek \& Ruprecht, Göttingen.

Speckmann, M., 2009, A Biblical vision for Africa's development, Cluster Publications, Pietermaritzburg.

Stark, R., 1996, The rise of Christianity: A sociologist reconsiders history, Princeton University Press, Princeton.

Taubes, J., 2004, The political theology of Paul, Stanford University Press, Stanford.

Van Aarde, A.G., 2000, 'The second letter to the Thessalonians. Reread as pseudepigraph', The Journal of Higher Critical Studies 3(2), 237-266.

Van Henten, J.W., 2012, 'Religion, Bible and Violence,' in J.W. van Henten \& P.G.R. De Villiers (eds.), Coping with Violence in the New Testament, pp. 3-22, Brill, Leiden.

Vom Brocke, C., 2001, Thessaloniki - Stadt des Kassander und Gemeinde des Paulus, Mohr Siebeck, Tübingen.

Wartenberg, T., 1990, The forms of power: From domination to transformation Temple University Press, Phildadelphia.

Zimmermann, R., 2009, 'The implicit ethics of New Testament writings: A draft on a new methodology for analyzing New Testament ethics', Neotestamenica 43(2), 399-423. 